SVU- International Journal of Veterinary Sciences, 2 (1): 20-35, 2019

Print ISSN: 2535-1826

Online ISSN: 2535-1877

Research Article

Open Access

\title{
Detection of Multi-Drug Resistant Food-borne Bacteria in Ready-to-Eat Meat Products in Luxor City, Egypt
}

\author{
Rania I. Younis ${ }^{1}$, Soad A. Nasef ${ }^{2}$, Wesam M. Salem ${ }^{3 *}$
}

${ }^{1}$ Reference Laboratory for Veterinary Quality Control on Poultry production (RLQP), Animal Health Institute, Luxor, Egypt, ${ }^{2}$ Reference Laboratory for Veterinary Quality Control on Poultry production (RLQP), Animal Health Institute, Dokki, Giza, 12618, Egypt, ${ }^{3}$ Department of Botany and Microbiology, Faculty of Science, South Valley University, 83523 Qena, Egypt.

\begin{abstract}
A total of five Escherichia coli and eight Salmonella isolates were recovered from ready-to-eat meat samples obtained from different street vendors in Luxor city, Egypt. Bacterial isolates were assayed for antimicrobial susceptibility, its virulence and antimicrobial resistance genes. The total number recovered positive Salmonella spp and E. coli were $8(6.66 \%)$ and $5(4.16 \%)$ respectively. All E. coli isolates were exhibited resistance against streptomycin and cephalothin. While all Salmonella isolates were resistant to nalidixic acid. PCR screening for virulence genes showed that $2(40 \%)$ of the E. coli $(\mathrm{O} 111: \mathrm{H} 4)$ serovar were positive for stx 1 , stx 2 , and eae A. While Salmonella enteritidis, typhimurium, and virchow hold invA, hilA and stn genes with percentage of 37.5, 25 and $12.5 \%$ respectively. The identified tetracycline resistance gene for $E$. coli isolates were tet $\mathrm{B}(60 \%)$, tet $\mathrm{C}(20 \%)$ and tet $\mathrm{D}(20 \%)$. The $\beta$-lactamase resistance gene bla $_{\mathrm{CTX}}$ was identified in $50 \%$ of Salmonella isolates represented by S. enteritidis, S. typhimurium and $S$. Virchow. The bla $a_{\mathrm{CMY}}$ genes were detected in S. typhimurium and S. infantis (37.5\%). These results highlighted the role of ready-to-eat meat as a potential source for multidrugresistant strains of E. coli and Salmonella. The current results indicate the need for applying hygienic practices in food outlets - especially in street vendors - to reduce the incidence of foodborne bacteria and to prevent future food-borne outbreaks in the studied area.
\end{abstract}

Keywords: Antibiotics, Escherichia coli, Meat products, Salmonella spp., Virulence genes.

DOI: $10.21608 /$ svu. 2019.23168

Received: October 15, $2018 \quad$ Accepted: December 5, 2018

Published: January 1, 2019

*Corresponding Author: Wesam M. Salem E-mail: wesam.salem@svu.edu.eg

Citation: Younis et al., Detection of Multi-Drug Resistant Food-borne Bacteria in Ready-to-Eat Meat Products in Luxor City, Egypt. SVU-IJVS 2019, 1 (2): 20-35.

Copyright: (c) Younis et al. This is an open access article distributed under the terms of the creative common attribution license, which permits unrestricted use, distribution and reproduction in any medium provided the original author and source are created.

Competing interest: The authors have declared that no competing interest exists. 


\section{Introduction}

Currently, increasing the antimicrobial resistance is a community health concern, and the spread of antimicrobial resistance are multipart complications that motivated by plentiful interrelated aspects, such as the misapplication of antibiotics (WHO, 2001). The relationship between severe use of antimicrobial agents and development of resistant bacteria is well documented for foodborne pathogens (Swartz, 2002). Bacterial foodborne pathogens are the most causative agents for human intestinal disease, especially in many countries. Approximately 1.8 million people died due to food-borne diarrheal infections each year in developing countries (Akbar and Anal, 2015; Nyabundi et al., 2017). Thus, enhanced research labors and investigation agendas are required from administration agencies with a great consideration and awareness from the food manufacturing and industries (Díaz-Sánchez et al. 2012). Street foods are contaminated with bacteria and other microbes, making them unsafe for consumers' health. In Egypt, street contaminated supplied food especially meat products may represent a risk due to the inadequate quality (Elamary et al., 2018; Noor, 2016). Such using of raw ingredients, insufficient workers hygiene, holding for long period, lead to contamination of food with pathogenic microorganisms (Gundogan et al., 2005). Escherichia coli and Salmonella spp. are Gram-negative short rods-bacilli bacteria, belong to the family Enterobacteriaceae. It successfully colonizes the gastrointestinal tract of mammals (Hammoudi and Aggad, 2008). Recently, E. coli has become recognized as a serious foodborne pathogen that associated with diseases outbreaks including diarrhea, hemorrhagic colitis and the life-threatening hemolyticuremic syndrome in humans (Hussein, 2007). Poultry meat is one of the frequent vehicles of salmonellosis as infectious diseases and is a major concern of public health (Elamary et al., 2018; Salem et al., 2017). Consumption of contaminated food by salmonella causes diarrhea, mild fever, nausea and abdominal pain with the symptoms developing in 12-72 hr. In lifethreatening cases, it can also lead to death (Abubakar et al., 2007). Consumption of ready-to-eat products is thought to be the major cause of the Salmonella outbreaks (Thai et al., 2012). Salmonella was found responsible for outbreaks of food-borne infections in Ghana (Andoh et al. 2017). Three different types of antigens were detected as adhering properties of somatic $\mathrm{O}$, flagellar $\mathrm{H}$, and capsular $\mathrm{Vi}$ - antigens and used to differentiate between more than 2500 serologically distinct types of Salmonella. (Madajczak and Szych, 2010). Numerous virulence factors have been associated with the family Enterobacteriaceae and they clarified its ability to cause disease such as toxins, verotoxin (shiga-like toxin), attaching and effecting mechanisms (eaeA) (Pass et al., 2000). The most common ready-to-eat meat products sold by street vendors in Egypt are Burger, Kofta, Kibda, and Shawirma which are usually sold in the form of sandwiches. Therefore, this study was conducted to evaluate the bacterial contamination of such street supplied meat products in Luxor city, Egypt. And to highlight the antimicrobial susceptibility of Escherichia coli and Salmonella isolates from ready to eat meat products with further molecular analysis of its virulence and antibiotic- resistant genes.

\section{Materials and Methods}

\section{Sample collection:}

One hundred twenty food samples (sandwiches) were randomly collected 
from the different street vendors in Luxor city. The samples in two different times were grouped into four categories: (Shawirma, Kofta, Burgers, and Liver/Kibda). All samples were collected aseptically and placed in sterile containers, stored at $4^{\circ} \mathrm{C}$, then transferred to the laboratory for bacterial isolation.

\section{I.1. Isolation of Salmonella spp. and Escherichia coli:}

The isolation of Salmonella and $E$. coli were performed according to Snyder and Atlas (2006). Briefly, 25 grams of each sample were transferred into a stomacher bag with $225 \mathrm{ml}$ of buffer peptone water (Sigma-Aldrich ${ }^{\circledR}$ 70179), the samples were incubated at $37^{\circ} \mathrm{C} \pm 1^{\circ} \mathrm{C} /$ $18 \pm 2$ h. For Salmonella isolation, serial dilution was made up and $0.1 \mathrm{ml}$ of each dilution was spread on RappaportVassiliadis Soy Peptone (Oxoid ${ }^{\circledR}$ CM0866) Broth and incubated at $41.5^{\circ} \mathrm{C} \pm 1{ }^{\circ} \mathrm{C} / 24$ $\mathrm{hr}$. The samples were plated on a selective medium such as XLD agar (HiMedia ${ }^{\circledR}$ Laboratories, Mumbai, India) for 18-24 hours at $37^{\circ} \mathrm{C}$. To detect E. coli, a loop-full of the incubated broth culture was then streaked onto eosin methylene blue agar (BioWorld, USA 30620025-1) plates as a selective medium then incubated at $37^{\circ} \mathrm{C}$ for $24 \mathrm{~h}$. Suspected colonies of E. coli and Salmonella $s p$. were picked up and identified by classical biochemical methods (Gram staining, citrate, indole, urease, triple sugar and lysine). E. coli isolates that were mainly identified by biochemical tests were then serologically identified according to Hammoudi and Aggad, 2008 by using rapid diagnosis $E$. coli antisera sets (Denka Seiken Co., Japan) for diagnosis of enteropathogenic types (Mirzaie et al., 2010) as follows:

Set 1: $O$ - antisera:
Polyvalent antisera 1: O1, O26, O86a, O111, O119, O127a and O128.

Polyvalent antisera 2: O44, O55, O125, O126, O146 and O166.

Polyvalent antisera 3: O18, O114, O142, O151, O157 and O158.

Polyvalent antisera 4: O2, O6, O27, O78, O148, $\mathrm{O} 159$ and $\mathrm{O} 168$.

Polyvalent antisera 5: O20, O25, O63, $\mathrm{O} 153$ and $\mathrm{O} 167$.

Polyvalent antisera 6: O8, O15, O115 and O169.

Polyvalent antisera 7: O28ac, O112ac, O124, O136 and O144.

Polyvalent antisera 8: O29, O143, 0152 and $\mathrm{O} 164$.

\section{Set 2: H- sera:}

H2, H4, H6, H7, H11, H18 and H21.

Salmonella isolates were primarily identified by biochemical tests, then subjected to serological identification that was carried out according to the WhiteKauffmann-Le Minor scheme (Guibourdenche et al. 2010) using Salmonella antiserum (Denka Sei ken Co., Japan).

\section{2. Detection of virulence and antibiotic} resistant genes of isolates:

Molecular characterization of the recovered E. coli and Salmonella spp were carried out by PCR, except the tet genes that were carried out by multiplex PCR. The encoding enterotoxins and antibiotic resistant genes (six for $E$. coli and five for Salmonella) were performed using twentytwo primers sets including forward and reverse. The extraction of DNA was carried according to QIAamp DNA mini kit instructions. All primer sequences and corresponding references are listed in Table (1). 
Table 1: Primers sequences, target genes, amplicon sizes and cycling conditions. ${ }^{a}$

\begin{tabular}{|c|c|c|c|c|c|c|c|c|}
\hline \multirow{2}{*}{$\begin{array}{l}\text { Target } \\
\text { gene }\end{array}$} & \multirow[b]{2}{*}{ Sequence } & \multirow{2}{*}{$\begin{array}{l}\text { Amplified } \\
\text { segment } \\
\text { (bp) }\end{array}$} & \multirow{2}{*}{$\begin{array}{c}\text { Primary } \\
\text { denaturation }\end{array}$} & \multicolumn{4}{|c|}{ Amplification ( 35 cycles) } & \multirow[b]{2}{*}{ References } \\
\hline & & & & $\begin{array}{c}\text { Secondary } \\
\text { denaturation }\end{array}$ & Annealing & Extension & $\begin{array}{c}\text { Final } \\
\text { Extension }\end{array}$ & \\
\hline \multicolumn{9}{|c|}{ Genes used for $E$. coli isolates } \\
\hline stx 1 & $\begin{array}{l}\text { 5'ACACTGGATGATC } \\
\text { TCAGTGG '3 } \\
\text { 5'CTGAATCCCCCTC } \\
\text { CATTATG ' } 3 \\
\end{array}$ & 614 & $95^{\circ} \mathrm{C} / 3 \mathrm{~min}$. & $95^{\circ} \mathrm{C} / 20 \mathrm{sec}$. & $\begin{array}{l}58^{\circ} \mathrm{C} / 40 \\
\text { sec. }\end{array}$ & $\begin{array}{c}72^{\circ} \mathrm{C} / 90 \\
\text { sec. }\end{array}$ & $\begin{array}{l}72^{\circ} \mathrm{C} / 5 \\
\text { min. }\end{array}$ & \multirow{2}{*}{$\begin{array}{l}\text { Dhanashree } \\
\text { and Mallya, } \\
2008\end{array}$} \\
\hline stx 2 & $\begin{array}{l}\text { 5'CCATGACAACGG } \\
\text { ACAGCAGTT ' } 3 \\
\text { 5'CCTGTCAACTGAG } \\
\text { CAGCACTTTG ' } 3 \\
\end{array}$ & 779 & $95^{\circ} \mathrm{C} / 3 \mathrm{~min}$. & $95^{\circ} \mathrm{C} / 20 \mathrm{sec}$. & $\begin{array}{l}58^{\circ} \mathrm{C} / 40 \\
\text { sec. }\end{array}$ & $\begin{array}{l}72^{\circ} \mathrm{C} / 90 \\
\text { sec. }\end{array}$ & $\begin{array}{l}72^{\circ} \mathrm{C} / 5 \\
\text { min. }\end{array}$ & \\
\hline$e a e \mathbf{A}$ & $\begin{array}{l}\text { 5'GTGGCGAATACT } \\
\text { GGCGAGACT ' } 3 \\
\text { 5'CCCCATTCTTTTT } \\
\text { CACCGTCG ' } 3\end{array}$ & 890 & $95^{\circ} \mathrm{C} / 3 \mathrm{~min}$. & $95^{\circ} \mathrm{C} / 20 \mathrm{sec}$. & $\begin{array}{l}58^{\circ} \mathrm{C} / 40 \\
\text { sec. }\end{array}$ & $\begin{array}{l}72^{\circ} \mathrm{C} / 90 \\
\text { sec. }\end{array}$ & $\begin{array}{l}72^{\circ} \mathrm{C} / 5 \\
\text { min. }\end{array}$ & $\begin{array}{c}\text { Mazaheri et } \\
\text { al., } 2014\end{array}$ \\
\hline $\operatorname{tet} \mathbf{B}$ & $\begin{array}{l}\text { 5'TTGGTTAGGGGCA } \\
\text { AGTTTTG '3 } \\
\text { 5'GTAATGGGCCAA } \\
\text { TAACACCG '3 }\end{array}$ & 695 & $94^{\circ} \mathrm{C} / 1 \mathrm{~min}$. & $60^{\circ} \mathrm{C} / 1 \mathrm{~min}$. & $\begin{array}{l}95^{\circ} \mathrm{C} / 3 \\
\text { min. }\end{array}$ & $\begin{array}{l}72^{\circ} \mathrm{C} / 2 \\
\text { min. }\end{array}$ & $\begin{array}{l}72^{\circ} \mathrm{C} / 7 \\
\text { min. }\end{array}$ & \multirow{3}{*}{$\begin{array}{l}\text { Ng et al., } \\
2001\end{array}$} \\
\hline tetC & $\begin{array}{l}\text { 5'CTTGAGAGCCTTC } \\
\text { AACCCAG '3 } \\
\text { 5'ATGGTCGTCATCT } \\
\text { ACCTGCC ' } 3\end{array}$ & 418 & $94^{\circ} \mathrm{C} / 1 \mathrm{~min}$. & $60^{\circ} \mathrm{C} / 1 \mathrm{~min}$. & $\begin{array}{l}95^{\circ} \mathrm{C} / 3 \\
\text { min. }\end{array}$ & $\begin{array}{l}72^{\circ} \mathrm{C} / 2 \\
\text { min. }\end{array}$ & $\begin{array}{l}72^{\circ} \mathrm{C} / 7 \\
\text { min. }\end{array}$ & \\
\hline tet $\mathrm{D}$ & $\begin{array}{l}\text { 5'AAACCATTACGG } \\
\text { CATTCTGC ' } 3 \\
\text { 5'AAACCATTACGG } \\
\text { CATTCTGC ' } 3 \\
\end{array}$ & 787 & $94^{\circ} \mathrm{C} / 1 \mathrm{~min}$. & $60^{\circ} \mathrm{C} / 1 \mathrm{~min}$. & $\begin{array}{c}95^{\circ} \mathrm{C} / 3 \\
\text { min. }\end{array}$ & $\begin{array}{l}72^{\circ} \mathrm{C} / 2 \\
\text { min. }\end{array}$ & $\begin{array}{l}72^{\circ} \mathrm{C} / 7 \\
\text { min. }\end{array}$ & \\
\hline \multicolumn{9}{|c|}{ Genes used for Salmonella isolates } \\
\hline $\operatorname{inv} \mathrm{A}$ & $\begin{array}{l}\text { 5'GTGAAATTATCGCC } \\
\text { ACGTTCGGGCA '3 } \\
\text { 5'TCATCGCACCGTCA } \\
\text { AAGGAACC '3 }\end{array}$ & 284 & $94^{\circ} \mathrm{C} / 5 \mathrm{~min}$. & $94^{\circ} \mathrm{C} / 30 \mathrm{sec}$. & $\begin{array}{l}55^{\circ} \mathrm{C} / 30 \\
\text { sec. }\end{array}$ & $\begin{array}{l}72^{\circ} \mathrm{C} / 90 \\
\text { sec. }\end{array}$ & $\begin{array}{l}72^{\circ} \mathrm{C} / 7 \\
\text { min. }\end{array}$ & $\begin{array}{c}\text { Shanmugas } \\
\text { amy et al., } \\
2011\end{array}$ \\
\hline $\operatorname{stn}$ & $\begin{array}{l}\text { 5'CTTTGGTCGTAAA } \\
\text { ATAAGGCG '3 } \\
\text { 5'TGCCCAAAGCAG } \\
\text { AGAGATTC ' } 3\end{array}$ & 260 & $94^{\circ} \mathrm{C} / 5 \mathrm{~min}$. & $94^{\circ} \mathrm{C} / 30 \mathrm{sec}$. & $\begin{array}{l}55^{\circ} \mathrm{C} / 30 \\
\text { sec. }\end{array}$ & $\begin{array}{l}72^{\circ} \mathrm{C} / 90 \\
\text { sec. }\end{array}$ & $\begin{array}{l}72^{\circ} \mathrm{C} / 7 \\
\text { min. }\end{array}$ & $\begin{array}{c}\text { Makino et } \\
\text { al., } 1999\end{array}$ \\
\hline hilA & 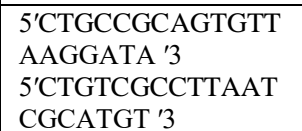 & 297 & $94^{\circ} \mathrm{C} / 5 \mathrm{~min}$. & $94^{\circ} \mathrm{C} / 30 \mathrm{sec}$. & $\begin{array}{l}55^{\circ} \mathrm{C} / 30 \\
\text { sec. }\end{array}$ & $\begin{array}{l}72^{\circ} \mathrm{C} / 90 \\
\text { sec. }\end{array}$ & $\begin{array}{l}72^{\circ} \mathrm{C} / 7 \\
\text { min. }\end{array}$ & $\begin{array}{l}\text { Guo et al., } \\
2000\end{array}$ \\
\hline bla $_{C T \mathbf{X}}$ & $\begin{array}{l}\text { 5'CGCTTTGCGATGT } \\
\text { GCAG '3 } \\
\text { 5'ACCGCGATATGCT } \\
\text { TGGT '3 }\end{array}$ & 550 & $94^{\circ} \mathrm{C} / 5 \mathrm{~min}$. & $94^{\circ} \mathrm{C} / 30 \mathrm{sec}$. & $\begin{array}{l}60^{\circ} \mathrm{C} / 45 \\
\text { sec. }\end{array}$ & $\begin{array}{l}72^{\circ} \mathrm{C} / 45 \\
\text { sec. }\end{array}$ & $\begin{array}{l}72^{\circ} \mathrm{C} / 10 \\
\text { min. }\end{array}$ & \multirow{2}{*}{$\begin{array}{l}\text { Ahmed et } \\
\text { al., } 2009\end{array}$} \\
\hline$b^{b l a} a_{C M Y}$ & $\begin{array}{l}\text { 5'GACGCCTCTTTCT }^{\prime} \text { CCACA '3 } \\
\text { 5'TGGAACGAAGGC } \\
\text { TACGTA '3 }\end{array}$ & 1007 & $94^{\circ} \mathrm{C} / 5 \mathrm{~min}$. & $94^{\circ} \mathrm{C} / 30 \mathrm{sec}$. & $\begin{array}{c}60^{\circ} \mathrm{C} / 45 \\
\text { sec. }\end{array}$ & $\begin{array}{c}72^{\circ} \mathrm{C} / 45 \\
\text { sec. }\end{array}$ & $\begin{array}{l}72^{\circ} \mathrm{C} / 10 \\
\text { min. }\end{array}$ & \\
\hline
\end{tabular}

${ }^{\text {a }}$ The specific amplified sequences for each primers were (Metabion, Germany).

I.2.1. DNA amplification for the selected virulence and antibiotic resistance genes of Salmonella:

The amplification was performed on a Thermal Cycler (Master cycler, Eppendorf, Hamburg, Germany). The reaction mixes invariably consisted of $5 \mu \mathrm{l}$ of the bacterial lysate, $5 \mu \mathrm{l}$ of $10 \mathrm{x}$ assay buffer for Taq polymerase containing $1.5 \mathrm{mM} \mathrm{MgCl}_{2}, 2$ $\mu 1$ of $10 \mathrm{mM}$ dNTP mix and $1.25 \mathrm{U}$ of Taq DNA polymerase. Then $1 \mu 1$ of different primers specific for Salmonella virulence genes (invA, hilA and stn) each of forward 
and reverse primer (10 pmol) were added as previously described (Table 1). Distilled water was added to bring the final volume to $50 \mu \mathrm{L}$. For antibiotic resistance genes, PCR amplifications were performed in a total volume of $50 \mu \mathrm{L}$ reactions containing $25 \mu \mathrm{L}$ DreamTaq Green PCR Master Mix (Thermo Scientific, St. Leon Roth, Germany), $2 \mu \mathrm{L}$ of each forward and reverse primer ( $\beta$-lactams- encoding genes; $b a_{\mathrm{CTX}}$ and/or bla $\left.a_{\mathrm{CMY}}\right)(10 \mathrm{pmol}), 20 \mu \mathrm{L}$ of sterile water and $1 \mu \mathrm{L}$ of DNA-mixture.

\section{I.2.2. Amplification reaction of E. coli:}

The amplification was performed on a Thermal Cycler (Master cycler, Eppendorf, Hamburg, Germany). PCR assays were carried out in a $50 \mu 1$ volume containing 1 $\mathrm{ml}$ of nucleic acid template prepared by using reference EHE isolates (approximately $30 \mathrm{ng}$ of DNA), $10 \mathrm{mM}$ Tris-HCl (pH 8.4), $10 \mathrm{mM} \mathrm{KCl,} 3 \mathrm{mM}$ $\mathrm{MgCl}_{2} ; 2 \mathrm{mM}$ concentrations of each primer (shiga toxins encoded by stx 1 and st $x 2$ genes, intimin surface protein encoded by eaeA gene), $0.2 \mathrm{mM}$ concentrations of each 2'-deoxynucleoside 5'-triphosphate, and $4 \mathrm{U}$ of AmpliTaq DNA polymerase (Perkin-Elmer).

\section{I.2.3. Multiplex PCR detection of tet genes:}

All isolates of tetracycline-resistant $E$. coli strains were assessed for carriage of the tetracycline resistance genes $t e t \mathrm{~B}$, tet $\mathrm{C}$ and tet $\mathrm{D}$. The method was optimized using reference $E$. coli strains with known tet genes as follows: a small amount of biomass from a bacterial colony was added to a sterile thin-walled reaction tube containing Taq Master Mix, primers, $\mathrm{MgCl}_{2}$, and distilled water. The multiplex PCR reaction mix (total $50 \mu \mathrm{l}$ ) included primers for tet $\mathrm{B}$, tet $\mathrm{C}(0.25 \mu \mathrm{M}$ each $)$ and tet $\mathrm{D}(3 \mu \mathrm{M})$ and $1.5 \mathrm{mM} \mathrm{MgCl}_{2}$.

Finally, $5 \mu \mathrm{l}$ of each amplicon was electrophoresed in $1.5 \%$ agarose gel
(Sigma -USA, stained with ethidium bromide, visualized and captured on UV transilluminator. A 100 bp DNA ladder was used as a marker for PCR products.

\section{Antimicrobial Susceptibility test:}

The antibiograms for all the recovered isolates were determined as described earlier by using disk diffusion test (Rodríguez-Tudela et al., 2003). The susceptibility of E. coli and Salmonella isolates was tested for 14 antibiotics from $B$-lactams group (Bioanalyze ${ }^{\circledR}$ ). The used antibiotics were Nalidixic acid; Oxacillin; Neomycin; Streptomycin; Penicillin; Erythromycin; Cephalothin; Kanamycin; sulfamethoxazole;

Ampicillin;

Chloramphenicol; Oxytetracycline; gentamycin and Ciprofloxacin. Interpretation of the results was performed according to clinical and laboratory standard institute guidelines (CLSI, 2007) to determine if the isolate is resistant, intermediate, or susceptible to the tested antibiotics.

\section{Results}

I. Prevalnce of E. coli and Salmonella spp. in ready-to-eat meat samples:

The incidence of $E$. coli and Salmonella isolated from the examined samples were illustrated in Table (2). Out of 120 ready-to-eat meat (RTE) samples, the total number recovered positive Salmonella spp and E. coli infections were $8(6.66 \%)$ and $5(4.16 \%)$ respectively. From all the infected samples, Kofta samples showed the highest prevalence of Salmonella isolates indicated as $4(13.3 \%)$ compared to the number of Kofta samples examined. While, Kofta and Burger samples showed an incidence of E. coli as $(6.6 \%)$ for both samples separately. Interestingly, E. coli was absent in all the tested liver samples (Kibda). 
Table 2: The incidence of E. coli and Salmonella isolated from ready-to-eat meat samples.

\begin{tabular}{lccc}
\hline \multirow{2}{*}{ Samples } & \multirow{2}{*}{ No } & \multicolumn{2}{c}{ Positive isolates ${ }^{\text {a }}$} \\
\cline { 3 - 4 } & & Salmonella sp. & E. coli \\
\hline Kofta & 30 & $4(13.3 \%)$ & $2(6.6 \%)$ \\
Shawirma & 30 & $1(3.3 \%)$ & $1(3.3 \%)$ \\
Burger & 30 & $1(3.3 \%)$ & $2(6.6 \%)$ \\
Kibda & 30 & $2(6.6 \%)$ & $0(0 \%)$ \\
\hline Total no. & 20 & $8(6.66 \%)$ & $5(4.16 \%)$
\end{tabular}

${ }^{a}$ Number and percentage of positive samples contaminated with Salmonella spp. and/or E. coli.

\section{Serotype and virulence genes of isolates:}

The serotypes of E. coli from the examined Kofta samples were Enteropathogenic E. coli (EPEC, O125:H21, $20 \%$ ) and Enterohemorrhagic E. coli (EHEC, O26:H11, 20\%), while in Shawirma, EPEC (O55:H7, 20\%). Moreover, in Burger EHEC,
$(\mathrm{O} 111: \mathrm{H} 4,40 \%)$ was identified. E. coli isolates were screened for virulence genes (stx $1, s t x 2$ and eaeA). In three E. coli serovars (O111:H4, O26:H11 and O125:H21) the gene encoding for stx 1 was detected. stx2 gene was detected in (O111:H4 and O55: H7) serovars. eae A gene was detected in 3 serovars O111:H4, O55: H7 and O26: H11 (Table 3). The serological examination of identified Salmonella isolates showed that two isolates were $S$. typhimurium from Kibda represented $(25 \%)$ from the total isolates, three isolates were $S$. enteritidis $(37.5 \%)$ two isolates from Kofta and one isolate from the Burger. Also, $S$. virchow and $S$. malade from Kofta, and $S$. infantis isolated from shawarma all of them represented (12.5\%). Salmonella isolates were screened for virulence genes encoded stn, invA, and hilA. The results showed that all serovars were positive for all the examined virulence genes except for $S$. malade (isolated from Kofta) that lacks stn gene, one isolate of $S$. enteritidis and $S$. infantis (isolated from Burger and Shawirma respectively) lack hilA gene (Table 3).

Table 3: Serotype and virulence genes of E. coli and Salmonella isolates obtained from ready-to-eat meat samples.

\begin{tabular}{|c|c|c|c|c|c|c|c|c|}
\hline \multirow{2}{*}{\multicolumn{2}{|c|}{$\begin{array}{c}\text { Isolate } \\
\text { characterization }\end{array}$}} & \multirow{2}{*}{$\begin{array}{l}\text { Serotype/ } \\
\text { group }\end{array}$} & \multirow{2}{*}{$\begin{array}{l}\text { No. of } \\
\text { isolates }\end{array}$} & \multirow{2}{*}{$\%$} & \multirow{2}{*}{ Sample } & \multicolumn{3}{|c|}{$\begin{array}{c}\text { Virulence genes } \\
\text { profile }\end{array}$} \\
\hline & & & & & & stx 1 & stx 2 & eaeA \\
\hline \multirow{4}{*}{ 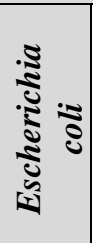 } & EPEC & O55: H7 & 1 & 20 & Shawirma & - & + & + \\
\hline & EHEC & O111: H4 & 2 & 40 & Burger & + & + & + \\
\hline & EHEC & O26: H11 & 1 & 20 & Kofta & + & - & + \\
\hline & EPEC & O125: H21 & 1 & 20 & Kofta & + & - & - \\
\hline & & & & & & $\operatorname{inv} \mathrm{A}$ & hilA & stn \\
\hline \multirow{5}{*}{ 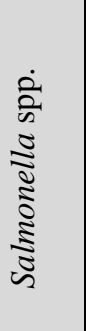 } & typhimurium & B & 2 & 25 & Kibda & + & + & + \\
\hline & enteritidis & D1 & 3 & 37.5 & $\begin{array}{c}2 \mathrm{Kofta} / 1 \\
\text { Burger }\end{array}$ & + & $+/-$ & + \\
\hline & virchow & $\mathrm{C} 1$ & 1 & 12.5 & Kofta & + & + & + \\
\hline & infantis & $\mathrm{C} 1$ & 1 & 12.5 & Shawirma & + & - & + \\
\hline & molade & $\mathrm{C} 2$ & 1 & 12.5 & Kofta & + & + & - \\
\hline
\end{tabular}

(+) Virulence genes detected in current study, (-) not detected. 
III. Detection of antibiotic-resistant genes by multiplex PCR:

E. coli isolates were screened for three antibiotic resistant genes (tet $\mathrm{B}$, tet $\mathrm{C}$, and tetD). The results showed that three E. coli serovars out of five $(60 \%)$ were positive for (tet $\mathrm{B}) ; 2$ serovars of EHEC: O111:H4 and 1 serovar O26:H11. While (40\%) from total $E$. coli isolates were positive for both (tet $\mathrm{C})$ and (tet $\mathrm{D}) ; 1$ serovar of EHEC O26:H11 (20\%) and 1 serovar of EPEC: O125:H21 (20\%) respectively (Table 4). Salmonella isolates were screened for antibiotic-resistant genes (bla $a_{\mathrm{CMY}}$ and $\left.b_{\text {latX }}\right)$. The results showed that two serovars of $S$. enteritidis, one $S$. typhimurium and $S$. virchow hold blactх genes (represented as 50\% from total Salmonella isolates), while two serovars (S. typhimurium and one S. infantis hold bla $\mathrm{CMY}_{\text {genes }}(37.5 \%)$ (Table 5).

\section{Antimicrobial susceptibility test:}

The antibiotic resistance of $E$. coli and Salmonella isolates against the tested 14 antibiotics with different disc potency was determined by disc diffusion method and the results showed that all $E$. coli isolates were resistant to Streptomycin (10mg/disc) and Cephalothin (30mg/disc). A high percentage $(80 \%)$ exhibited resistance to Penicillin (10mg/disc), Oxacillin $(10 \mathrm{mg} / \mathrm{disc})$ and Erythromycin (15mg/disc). Nalidixic acid and Sulfamethoxazole resistance were observed in almost 60\%. Furthermore, $60 \%$ of isolates were sensitive Kanamycin (30mg/disc) while $80 \%$ sensitive for Gentamicin (10mg/disc) (Table 4). All Salmonella isolates were resistant to Nalidixic acid (30mg/disc), while $88 \%$ were resistant to Oxacillin $(10 \mathrm{mg} / \mathrm{disc})$ and Neomycin (30mg/disc). Streptomycin, Penicillin (10mg/disc) and Erythromycin $(15 \mathrm{mg} /$ disc) resistances were observed in almost 75\%. Cephalothin (30mg/disc) resistance was $62.5 \%$. Kanamycin (30mg/disc), Sulfamethoxazole (25mg/disc) and Ampicillin (10mg/disc) resistance were $50 \%$. Furthermore, $50 \%$ of Salmonella isolates were sensitive to Oxytetracycline $(30 \mathrm{mg} /$ disc), Gentamicin (10mg/disc) and Ciprofloxacin (15mg/disc) (Table 5).

Table 4: Resistance genes detected in antibiotic resistant $E$. coli isolates.

\begin{tabular}{|c|c|c|c|c|c|}
\hline \multicolumn{4}{|c|}{ Phenotype of Antibiotic (\%) ${ }^{a}$} & \multicolumn{2}{|c|}{ Genes detected by PCR } \\
\hline $\begin{array}{c}\text { Antimicrobial } \\
\text { agent (mg/disc) }\end{array}$ & $\mathbf{R}$ & $\mathbf{M}$ & $\mathbf{S}$ & $\begin{array}{c}\text { Resistance } \\
\text { genes }\end{array}$ & No. of positive serotype / $^{\text {\% }}$ \\
\hline S-10 & 100 & $\mathbf{0}$ & $\mathbf{0}$ & tet $\mathrm{B}$ & 3: (2) O111:H4; O26:H11 / (60\%) \\
\hline $\mathrm{CN}-30$ & 100 & $\mathbf{0}$ & $\mathbf{0}$ & $\begin{array}{l}\text { tet } \mathrm{C} \\
\text { tet } \mathrm{D}\end{array}$ & $\begin{array}{l}\text { 1: O26:H11 / (20\%) } \\
\text { 1: O125:H21 / (20\%) }\end{array}$ \\
\hline P-10 & 80 & 20 & $\mathbf{0}$ & & \\
\hline OX-10 & 80 & $\mathbf{0}$ & 20 & & \\
\hline E-15 & 80 & $\mathbf{0}$ & 20 & & \\
\hline NA-30 & 60 & 40 & $\mathbf{0}$ & & \\
\hline SXT-25 & 60 & 20 & 20 & & \\
\hline AM-10 & 40 & 60 & $\mathbf{0}$ & & \\
\hline T-30 & 40 & 40 & 20 & & \\
\hline CP-15 & 40 & 40 & 20 & & \\
\hline $\mathbf{N}-30$ & 40 & 20 & 40 & & \\
\hline C-30 & 40 & $\mathbf{0}$ & 60 & & \\
\hline K-30 & 20 & 20 & 60 & & \\
\hline G-10 & 20 & $\mathbf{0}$ & 80 & & \\
\hline
\end{tabular}

Antimicrobial susceptibility of E. coli isolates against $\beta$-lactams group. ${ }^{\text {a: }}$ R: Resistant; M: Moderate; S: Sensitive; NA: Nalidixic acid; OX: Oxacillin; N: Neomycin; S: Streptomycin; P: Penicillin; E: Erythromycin; 
CN: Cephalothin; K: Kanamycin; SXT: sulfamethoxazole; AM: Ampicillin; C: Chloramphenicol; T: Oxytetracycline; G: gentamycin; CP: Ciprofloxacin. 10, 15, 25 and 30: antibiotic concentration (mg/disc). b: Number of positive serovars for each detected gene and its percentage compared to the total E. coli isolates.

Table 5: Resistance genes detected in antibiotic resistant Salmonella isolates.

\begin{tabular}{|c|c|c|c|c|c|}
\hline \multicolumn{4}{|c|}{ Phenotype of Antibiotic (\%) ${ }^{a}$} & \multicolumn{2}{|r|}{ Genes detected by PCR } \\
\hline $\begin{array}{c}\text { Antimicrobial } \\
\text { agent (mg/disc) }\end{array}$ & $\mathbf{R}$ & $\mathbf{M}$ & $\mathbf{S}$ & $\begin{array}{l}\text { Resistance } \\
\text { genes }\end{array}$ & No. of positive serotype / $^{\mathrm{b}}$ \\
\hline NA-30 & 100 & $\mathbf{0}$ & $\mathbf{0}$ & blactх & $\begin{array}{l}\text { 4: (2) S. enteritidis, (1) S. typhimurium, } \\
\text { (1) S. Virchow / }(50 \%)\end{array}$ \\
\hline OX-10 & 88 & 12 & $\mathbf{0}$ & bla $a_{\mathrm{CMY}}$ & 3: (2) S. typhimurium, (1) S. infantis / (37.5\%) \\
\hline N-30 & 88 & 12 & 0 & & \\
\hline S-10 & 75 & 25 & 0 & & \\
\hline P-10 & 75 & 12.5 & 12.5 & & \\
\hline E-15 & 75 & 0 & 25 & & \\
\hline $\mathrm{CN}-30$ & 62.5 & 12.5 & 25 & & \\
\hline K-30 & 50 & 37.5 & 12.5 & & \\
\hline SXT-25 & 50 & 25 & 25 & & \\
\hline AM-10 & 50 & $\mathbf{0}$ & $\mathbf{0}$ & & \\
\hline C-30 & 37.5 & 25 & 37.5 & & \\
\hline T-30 & 37.5 & 12.5 & 50 & & \\
\hline G-10 & 25 & 25 & 50 & & \\
\hline CP-15 & 12.5 & 12.5 & 50 & & \\
\hline
\end{tabular}

Antimicrobial susceptibility of Salmonella isolates against $\beta$-lactams group. a: R: Resistant; M: Moderate; S: Sensitive; NA: Nalidixic acid; OX: Oxacillin; N: Neomycin; S: Streptomycin; P: Penicillin; E: Erythromycin; CN: Cephalothin; K: Kanamycin; SXT: sulfamethoxazole; AM: Ampicillin; C: Chloramphenicol; T: Oxytetracycline; G: gentamycin; CP: Ciprofloxacin. 10, 15, 25 and 30: antibiotic concentration (mg/disc). ${ }^{\text {b: }}$ Number of positive serovars for each detected gene and its percentage compared to the total Salmonella isolates.

\section{Discussion}

The presence of Escherichia coli in ready-to-eat meat indicates non- hygienic conditions for food preparations (Nyabundi et al., 2017). E. coli as Enteropathogenic in meat products provide an evidence of contamination of fecal or water origin. In this study (Table 2)., the percentage of $E$. coli in Kofta samples were $(6.6 \%)$ which lower than that obtained by Ahmed and Shimamoto (2014) Regarding to percentage of E. coli in the Burger $(6.6 \%)$, this result was lower than incidences recorded by Kalantari et al. (2012) $(16.4 \%)$. On the other hand, the present study for Shawirma samples were $(3.3 \%)$ that was different from those reported by Vazgecer et al. (2004) (31\%). While these results in agreement with the results obtained by Hemeg (2018) who reported the prevalence of $E$. coli O111, O55 and O26 in food samples. Interestingly, the absence of $E$. coli in this study was from liver samples (Kibda) which disagree with Zaghloul et al. (2014), who isolate E. coli from $32 \%$ of examined liver sandwiches. The absence of $E$. coli in heat-treated food as RTE liver sandwiches indicates an adequate cooking hygiene without postprocessing contamination. On the other hand, the presence of these microbes in liver sandwiches can be linked to improper handling and processing, use of contaminated raw materials or the use of dirty processing utensils like knife and trays (Salma et al., 2015). On the other hand, Salmonella is responsible for disease in humans. It has been the leading cause of many outbreaks and infections around the world and is considered as one of the major causes of human gastroenteritis worldwide (Rasschaert et al., 2005). The current results of Kofta showed the highest percentage $(13.3 \%)$ of Salmonella spp. that 
were nearly like that recorded by Zaghloul et al. (2014). Moreover, the incidence of Salmonella isolated from Kibda (6.6\%) were like the results from Shaltout et al. (2013). On the other hand, only one Salmonella isolate was detected in Shawirma and Burger samples that represented $(3.3 \%)$ and these results was higher than those obtained by Al-Mutairi (2011). While, In Lebanon, Harakeh et al. (2005) reported prevalence's of Salmonella $7.4 \%$ in meat pies and Shawirma.

Shiga toxin-producing E. coli (STEC) may cause food-borne infections leading to dangerous diseases in humans. The outcomes of STEC infections may range from asymptomatic carriage to uncomplicated diarrhea to the severe symptoms of hemorrhagic colitis (HC) and hemolytic-uremic syndrome (HUS). Owing to their human pathogenicity, some STEC strains are also designated as enterohemorrhagic E. coli (EHEC) (Levine, 1987). EHEC strains comprise a subgroup of STEC and are characterized by certain serotypes, which are frequently associated with outbreaks and severe clinical illness (Bugarel et al., 2010). In recent years, cumulative evidence from numerous countries has indicated that up to 30 to $60 \%$ of human EHEC infections are caused by non-O157 EHEC (EFSA, 2013). Remarkably, the current study regarding the serotypes of $E$. coli from the examined Kofta and burger samples were Enterohemorrhagic E. coli (EHEC, O26:H11, 20\%) and (O111:H4, 40\%) respectively. Some E. coli strains were isolated from different ready-to-eat meat products by Ahmed and Shimamoto (2014) who isolated E. coli O157:H7 (1.6\%) from fresh beef samples, and this results in contrast with current study which detected O125: H21(20\%) and EHEC O26: H11 (20\%), while in Shawirma O55: H7 (20\%).
Moreover, in Burger O111: H4 (40\%) were identified in this study (Table 3). (AlMutairi, 2011) reported that out of seven isolates of $E$. coli recovered from Kofta sample, six isolates $(85.7 \%)$ were serologically typed as Enteropathogenic $E$. coli, also from five isolates of $E$. coli from Shawirma sample, three isolates were Enteropathogenic with an incidence of $60 \%$. Out of the 15 strains, 12 E. coli serovars isolated from meat product samples belonged to the serovars: O166; O78; O126; O55; O26; O20; O25: K4; O114; O125: K70 and O116. Similar E. coli serotypes were isolated from meat products were previously recorded by Hessain et al. (2015); Zaghloul et al. (2014); Ahmed and Shimamoto (2014). Regarding the Salmonella isolates in this study, S. enteritidis were $(37.5 \%)$, S. typhimurium (25\%), S. virchow, S. infantis and $S$. malade were (12.5\%) (Table 3). This result was higher than the results obtained by Shaltout et al. (2013) who isolated $S$. enteritidis $(4 \%)$ and $S$. typhimurium (4\%) from cooked meat. The variation in the results may be due to the differences in the production process, handling from producers to consumers and the effectiveness of hygienic measures applied during production. Most of Enterobacteriaceae human diseases due to strains that produce either Shiga toxin 1 (stx1) and/or Shiga toxin 2 (st $x 2)$ (Brudzinski and Harrison, 1998). The pathogenicity of $E$. coli strains was due to genes expression for Shiga toxins (stx genes) and intimin; a virulence factor that is an outer membrane protein (eaeA) (Beutin et al., 2004). The predominance of $s t x 2$ either alone or in combination with stx 1 considered to be the most important virulence factor (Kahali et al., 2004). In current study, detection of virulence genes clarified the presence of stx 1, st $x 2$ and eaeA genes in O111:H4 isolates, while the presence of stx2, eaeA genes in O55: $\mathrm{H} 7$ 
isolates. Also, O26: $\mathrm{H} 11$ isolates were positive for both stx 1 and eae A and isolates of $\mathrm{O} 125: \mathrm{H} 21$ contain only stx 1 gene (Table 3). Meanwhile, these results nearly in agreement with Mohammed et al. (2014) who detected stx and eaeA genes from the isolates of O55:H7. Also, (DíazSánchez et al. (2012) who found that $E$. coli serovars O166:O28 proved to have the two genes (stx1, stx2), and O119 serovars were positive for stx 1 , st 2 genes. Also, O86 isolates had the only stx 2 gene. Most of the genes required for Salmonella virulence are clustered within five Salmonella pathogenicity islands (SPI-1SPI-5), which contributes to its success as an intracellular pathogen (Marcus et al., 2000). Some virulence genes such as the chromosomally encoded stn (Salmonella enterotoxin gene) are not located on SPIs. These virulence genes act via maintenance of Salmonella membrane composition and integrity to play an important role in the virulence of Salmonella (Nakano et al., 2012; 2015). The PCR results of salmonella isolates for the presence of invA, hilA and stn in $S$. enteritidis, $S$. typhimurium and $S$. virchow while the presence of invA and hilA in S. malade. Also, invA and stn were positive in other isolates of $S$. enteritidis and $S$. infantis and this result was illustrated in Table (3). In current study, where the stn gene was prevalent among Salmonella isolates as evidenced by PCR (90\%) and this result nearly in agreement with Ammar et al. (2016) who reported a wide distribution of this gene $(100 \%)$ had also been recorded earlier among Salmonella isolates. The inv A gene has been widely used in studies for the detection of Salmonella in food samples (Chacón et al., 2010). In a study on the prevalence of virulence genes in non-typhoidal Salmonella isolated from humans, animals and food products in developing countries, Bangera et al. (2018) observed the high prevalence of strains carrying invA gene and this percentage in agreement with current study $(100 \%)$. The hilA gene encodes an OmpR/ToxR transcriptional regulator that activates the expression of invasion genes and has an important role in Salmonella pathogenicity (Crâciunaş et al., 2012). In a study conducted by Cardona-Castro et al. (2002), the hilA gene was detected in all the tested Salmonella isolates. In our results, hilA gene has been detected in all isolated Salmonella serovars except $S$. infantis (isolated from shawarma) and one isolate of $S$. enteritidis (isolated from Burger) (Table 3). Interestingly, routine PCR test confirmed the presence of all detected virulence genes (stn, inv $\mathrm{A}$, and hilA) in most of the isolated Salmonella. On the other hand, Bradford (2001) who indicated that up to $90 \%$ of ampicillin resistance in $E$. coli is due to the production of inactivating $\beta$ - lactams enzymes such as TEM-1. Also, Naber et al. (2008) who demonstrated the resistance to ciprofloxacin in E. coli was $21.6 \%$. These results are almost in agreement with our results (Table 4). But also, our result different with the results reported by (Mohammed et al., 2014) who observed that the resistance to one or more antimicrobial agents was found in 22 isolates of $E$. coli $(14.7 \%)$ detected from the total of 150 samples and a pattern of multiple drug resistance was observed. The distribution of resistance determinants for tetracycline was assessed by PCR in the resistant isolates. The most common resistance determinants were tet $\mathrm{B}(60 \%)$, tetC and D (20\%) (Table 4). In this study, the presence of multidrug-resistant $E$. coli to $B$-lactams groups is attributable to the acquired ability of the strains to produce $B$ lactamase, which hydrolyzes $B$-lactams ring, rendering the entire compound inactive. Osaili et al. (2014) reported that most Salmonella isolates were resistant to the majority of antibiotics tested. Harakeh 
et al. (2005) also found that 86 and $57 \%$ of the Salmonella isolates from meat-based fast food in Lebanon were resistant to trimethoprim-sulfamethoxazole and gentamicin, respectively. Moreover, (Diarra and Malouin, 2014) also reported a similar pattern of resistance against $B$ lactams antibiotics such as ampicillin. This resistance was associated with various antibiotic resistant gene determinants (bla ${ }_{\mathrm{CMY}}-1$, bla $a_{\mathrm{CMY}}-2$, and bla $a_{\mathrm{CTX}}$ ) (Liebana et al., 2013, Clemente et al., 2013). The previous results are in agreeing with our results where bla $a_{\mathrm{CTX}}$ and bla $a_{\mathrm{CMY}}$ genes were observed in $50 \%$ and $37.5 \%$ serovars, respectively (Table 5).

In conclusion, the prevalence's of both Salmonella and E. coli, at ready to eat meat products in Luxor city- Egypt, were high compared with those in other countries in the region, as earlier was published; consequently, obligatory implementation of strict food safety regulations in restaurants that sell high-risk meat products should be incessantly imposed and checked by regulatory agencies in Egypt for food safety.

\section{Conflict of interest statement}

The authors declare that they have no conflict of interest.

\section{References}

Abubakar I, Irvine L, Aldus CF, Wyatt GM, Fordham R, Schelenz S, Shepstone L, Howe A, Peck M, Hunter PR (2007). A systematic review of the clinical, public health and cost-effectiveness of rapid diagnostic tests for the detection and identification of bacterial intestinal pathogens in faeces and food. Health technology assessment (Winchester, England).

Ahmed AM, Shimabukuro H, Shimamoto
$\mathrm{T}$ (2009). Isolation and molecular characterization of multidrug-resistant strains of Escherichia coli and Salmonella from retail chicken meat in Japan. Journal of Food Science, 74 (7): 405-410.

Ahmed AM, Shimamoto T (2014). Isolation and molecular characterization of Salmonella enterica, Escherichia coli O157:H7 and Shigella spp. from meat and dairy products in Egypt. International Journal of Food Microbiology, 168169: 57-62.

Akbar A, Anal AK (2015). Isolation of Salmonella from ready-to-eat poultry meat and evaluation of its survival at low temperature, microwaving and simulated gastric fluids. Journal of Food Science and Technology, 52: 3051-3057.

Al-Mutairi MF (2011). The incidence of enterobacteriaceae causing food poisoning in some meat products. Advance Journal of Food Science and Technology, 3(2): 116-121.

Ammar AM, Mohamed AA, El-Hamid MIA, El-Azzouny MM (2016). Virulence genotypes of clinical Salmonella serovars from broilers in Egypt. Journal of Infection in Developing Countries, 10 (4): 337346.

Andoh LA, Ahmed S, Olsen JE, ObiriDanso K, Newman MJ, Opintan JA, Barco L, Dalsgaard A (2017). Prevalence and characterization of Salmonella among humans in Ghana. Tropical Medicine and Health, 45 (1): 1-11.

Bangera S, Umakanth S, Bhat R, Kamath A, Ballal M, Mukhopadhyay A (2018). Serovar profile and detection 
of inva virulence gene among nontyphoidal Salmonellae serovars isolated from acute gastroenteritis cases in coastal Karnataka, Southern India. Asian Journal of Pharmaceutical and Clinical Research, 11: 162-166.

Beutin L, Krause G, Zimmermann S, Kaulfuss S, Gleier K (2004). Characterization of Shiga ToxinProducing Escherichia coli Strains Isolated from Human Patients in Germany over a 3-Year Period. Journal of Clinical Microbiology, 42 (3):1099-1108.

Bradford P (2001). Extended spectrum betalactamase in the 21 century: characterization, epidemiology, and detection of this important resistant threat. Clinical Microbiol Reviews, 14 (4):933- 951 .

Brudzinski L, Harrisom MA (1998). Influence of Incubation Conditions on Survival and Acid Tolerance Response of Escherichia coli O157:H7 and Non-O157:H7 Isolates Exposed to Acetic Acid. Journal of Food Protection, 61(5): 542-546.

Bugarel M, Beutin L, Martin A, Gill A, Fach P (2010). Micro-array for the identification of Shiga toxinproducing Escherichia coli (STEC) sero-pathotypes associated with hemorrhagic colitis and hemolytic uremic syndrome in humans. International Journal of Food Microbiology, 142:318-329

Cardona-Castro N, Restrepo-Pineda E, Correa-Ochoa M (2002). Detection of hilA gene sequences in serovars of Salmonella enterica subspecies enterica. Memorias do Instituto Oswaldo Cruz, 97 (8): 1153-1156.
Chacón L, Barrantes K, García C, Achí R (2010). Estandarización de una PCR para la detección del gen invA de Salmonella spp. en lechuga. Revista de la Sociedad Venezolana de Microbiología. 30, 18-23.

Clemente L, Manageiro V, Ferreira E, Jones-Dias D, Correia I, Themudo P, Albuquerque T, Caniça M (2013). Occurrence of extended-spectrum $\beta$ lactamases among isolates of Salmonella enterica subsp. enterica from food-producing animals and food products, in Portugal. International Journal of Food Microbiology, 167 (2): 221-228.

Clinical and laboratory standared institute (CLSI) guidelines (2007). Performance standared for antimicrobial susceptibility testing. $17^{\text {th }}$ information supplement, 16 (1).

Crăciunaş C, Keul A-L, Flonta M, Cristea M (2012). DNA-based diagnostic tests for Salmonella strains targeting hilA, agfA, spvC and sef genes. Journal of Environmental Management, 95: S15-S18.

Dhanashree B, Mallya PS (2008). Detection of shiga-toxigenic Escherichia coli (STEC) in diarrhoeagenic stool \& meat samples in Mangalore, India. The Indian Journal of Medical Research, 128: 271-277.

Diarra MS, Malouin F (2014). Antibiotics in Canadian poultry productions and anticipated alternatives. Frontiers in Microbiology, 5: 282

Díaz-Sánchez S, Sánchez S, Sánchez M, Herrera-León S, Hanning I, Vidal D (2012). Detection and characterization of Shiga toxin-producing Escherichia coli in game meat and ready-to-eat 
meat products. International Journal of Food Microbiology, 160: 179-182.

Elamary RB, Shibat El-hamed DMW, Sayed WF, Salem WM. (2018). In vitro and In vivo Molecular Studies on The Effect of Some Antibiotics and Allium sativum Extract on Some Escherichia coli Serovars Isolated from Chicken. SVU-International Journal of Veterinary Sciences, 1 (2): 33-49.

European Food Safety Authority (EFSA) (2013). Scientific opinion on VTECseropathotype and scientific criteria regarding pathogenicity assessment. EFSA Journal, 11:31-38.

Guibourdenche M, Roggentin P, Mikoleit M, Fields PI, Bockemühl J, Grimont PAD, Weill F-X (2010). Supplement 2003-2007 (No. 47) to the WhiteKauffmann-Le Minor scheme. Research in Microbiology, 161: 2629.

Gundogan N, Citak S, Yucel N, Devren A (2005). A note on the incidence and antibiotic resistance of Staphylococcus aureus isolated from meat and chicken samples. Meat Science, 69: 807-810.

Guo X, Chen J, Beuchat LR, Brackett RE (2000). PCR detection of Salmonella enterica serotype Montevideo in and on raw tomatoes using primers derived from hilA. Applied and Environmental Microbiology, 66 (12): 5248-5252.

Hammoudi A, Aggad H (2008). Antibioresistance of Escherichia coli strains isolated from chicken colibacillosis in western Algeria. Turkish Journal of Veterinary and Animal Sciences, 32(2): 123-126.
Harakeh S, Yassine $H$, Gharios $M$, Barbour E, Hajjar S, El-Fadel M, Toufeili I, Tannous R (2005). Isolation, molecular characterization and antimicrobial resistance patterns of Salmonella and Escherichia coli isolates from meat-based fast food in Lebanon. Science of the Total Environment, 341(1-3): 33-44.

Hemeg, H. A. (2018). Molecular characterization of antibiotic resistant Escherichia coli isolates recovered from food samples and outpatient Clinics, KSA. Saudi Journal of Biological Sciences, 25: 928-931.

Hessain AM, Al-Arfaj AA, Zakri AM, ElJakee JK, Al-Zogibi OG, Hemeg HA, Ibrahim IM (2015). Molecular characterization of Escherichia coli O157: H7 recovered from meat and meat products relevant to human health in Riyadh, Saudi Arabia. Saudi Journal of Biological Sciences, 22 6): 725-729.

Hussein HS (2007). Prevalence and pathogenicity of Shiga toxinproducing Escherichia coli in beef cattle and their products. Journal of Animal Science, 85 (13): 63-72.

Kahali S, Sarkar B, Rajendran K, Khanam J, Yamasaki S, Nandy RK, Bhattacharya SK, Ramamurthy $\mathrm{T}$ (2004). Virulence Characteristics and Molecular Epidemiology of Enteroaggregative Escherichia coli Isolates from Hospitalized Diarrheal Patients in Kolkata, India Journal of Clinical Microbiology, 42: 41114120.

Kalantari S, Sepehri G, Bahrampour A, Sepehri E (2012). Determination of bacterial contamination isolated from Sandwiches in Kerman City and their resistance to commonly used 
antimicrobials. Archives of Applied Science Research, 4(2): 1100-1105.

Liebana E, Carattoli A, Coque TM, Hasman H, Magiorakos AP, Mevius D, Peixe L, Poirel L, SchuepbachRegula G, Torneke K, Torren-Edo J, Torres C, Threlfall J (2013). Public health risks of enterobacterial isolates producing extended-spectrum $\beta$ lactamases or AmpC $\beta$-lactamases in food and food-producing animals: An EU perspective of epidemiology, analytical methods, risk factors, and control options. Clinical Infectious Diseases, 56 (7): 1030-1037.

Levine MM. (1987). Escherichia coli that cause diarrhea: enterotoxigenic, enteropathogenic, entero-invasive, enterohemorrhagic, and enteroadherent. Journal of Infectious Diseases, 155:377-389.

Madajczak G, Szych J (2010). Evaluation of Premi®Test Salmonella kit for identification of not-typabe by conventional methods Salmonella. Medycyna Doświadczalna i Mikrobiologia, 62 (1): 29-36.

Makino S, Kurazono H, Chongsanguam M, Hayashi H, Cheun H, Suzuki S, Shirahata T (1999). Establishment of the PCR system specific to Salmonella spp. and its application for the inspection of food and fecal samples. The Journal of veterinary medical science / the Japanese Society of Veterinary Science, 61 (11): 1245-1247.

Marcus SL, Brumell JH, Pfeifer CG, Finlay BB (2000). Salmonella pathogenicity islands: Big virulence in small packages. Microbes and Infection. 2 (2): 145-156.

Mazaheri S, Ahrabi SS, Aslani MM
(2014). Shiga toxin-producing Escherichia coli isolated from lettuce samples in Tehran, Iran. Jundishapur Journal of Microbiology, 7 (9): e12346.

Mirzaie S, Hassanzadeh M, Ashrafi I (2010). Identification and characterization of Salmonella isolates from captured house sparrows. Turkish Journal of Veterinary \& Animal Sciences, 34 (2): 181- 186.

Mohammed MA, Sallam KI, Eldaly EAZ, Ahdy AM, Tamura T (2014). Occurrence, serotypes and virulence genes of non-O157 Shiga toxinproducing Escherichia coli in fresh beef, ground beef, and beef burger. Food Control, 37: 182-187.

Naber KG, Roscher K, Botto H, Schaefer V (2008). Oral levofloxacin 500mg once daily in the treatment of chronic bacterial prostatitis. International Journal of Antimicrobial Agents, 32: 145-153.

Nakano M, Yamasaki E, Ichinose A, Shimohata T, Takahashi A, Akada JK, Nakamura K, Moss J, Hirayama T, Kurazono H (2012). Salmonella enterotoxin (Stn) regulates membrane composition and integrity. Disease Models \& Mechanisms, 5 (4): 515521.

Nakano M, Yamasaki E, Moss J, Hirayama T, Kurazono H (2015). Study of the Stn Protein in Salmonella; A Regulator of Membrane Composition and Integrity. In: Salmonella: Methods and Protocols: Second Edition. , 127-138.

$\mathrm{Ng}$ LK, Martin I, Alfa M, Mulvey M (2001). Multiplex PCR for the detection of tetracycline resistant 
genes. Molecular and Cellular Probes, 15 (4): 209-215.

Noor R (2016). Microbiological quality of commonly consumed street foods in Bangladesh. Nutrition and Food Science, 46: 130-141.

Nyabundi D, Onkoba N, Kimathi R, Nyachieo A, Juma G, Kinyanjui $P$, Kamau J (2017). Molecular characterization and antibiotic resistance profiles of Salmonella isolated from fecal matter of domestic animals and animal products in Nairobi. Tropical Diseases, Travel Medicine and Vaccines 3 (1): 2.

Osaili, TM, Al-Nabulsi AA, Shaker RR, Jaradat ZW, Taha M, Al-Kherasha M, Meherat M, Holley R. (2014). Prevalence of Salmonella Serovars, Listeria monocytogenes, and Escherichia coli O157:H7 in Mediterranean Ready-to-Eat Meat Products in Jordan. Journal of Food Protection, 77 (1): 106-111.

Pass M, Odedra R, Batt R (2000). Multiplex PCRs for identification of Escherichia coli virulence genes. Journal of Clinical Microbiology, 38: 2001-2004.

Rasschaert G, Houf K, Imberechts $\mathrm{H}$, Grijspeerdt K, De Zutter L, Heyndrickx M (2005). Comparison of five repetitive-sequence-based PCR typing methods for molecular discrimination of Salmonella enterica isolates. Journal of Clinical Microbiology, 43 (8): 3615-3623.

Rodríguez-Tudela JL, Barchiesi F, Bille J, Chryssanthou E, Cuenca-Estrella M, Denning D, Donnelly JP, Dupont B, Fegeler W, Moore C, Richardson M, Verweij PE (2003). Method for the determination of minimum inhibitory concentration (MIC) by broth dilution of fermentative yeasts. Clinical Microbiology and Infection, 9 (8): 18.

Salma JIM, Ali MA, Takwa HI (2015). Prevalence of Some Food-borne Pathogens in Cooked Liver Sandwich. 2nd Conference of Food Safety, Suez Canal University, Faculty of Veterinary Medicine, (1): 82-89.

Salem WM, Shibat El-hamed DMW, Sayed WF, Elamary RB (2017). Alterations in virulence and antibiotic resistant genes of multidrug-resistant Salmonella serovars isolated from poultry: The bactericidal efficacy of Allium sativum. Microbial Pathogenesis, 108: 91-100.

Shaltout, F.A., Amani, M. Salem; Mahmoud, A.H., Abd Elraheem KA (2013). Bacterial Aspect of Cooked Meat and Edible Offal at Street Vendors Level. Benha Veterinary Medical Journal, 24(1): 320-328.

Shanmugasamy M, Velayutham T, Rajeswar J (2011). Inv A gene specific PCR for detection of Salmonella from broilers. Veterinary World, 4 (12): 562- 564.

Snyder J, Atlas R. (2006). Handbook of media for clinical microbiology. Boca Raton: CRC Press. 1- 544.

Swartz MN. (2002). Human diseases caused by foodborne pathogens of animal origin. Clinical Infectious diseases, 34 (Suppl 3): S111-122.

Thai TH, Hirai T, Lan NT, Yamaguchi R (2012). Antibiotic resistance profiles of Salmonella serovars isolated from retail pork and chicken meat in North Vietnam. International Journal of Food Microbiology, 156: 147-151. 
Vazgecer B, Ulu H, Oztan A (2004). Microbiological and chemical qualities of chicken döner kebab retailed on the Turkish restaurants. Food Control, 15: 261-264.

WHO: World Health Organization (2001). Global strategy for containment of antimicrobial resistance. Geneva: publication nr WHO/CSR/DRS/2001.
Zaghloul RA, El-Shenawy MA, Neweigy NA, Abou-Aly HE, El-dairouty RK, El-Kholy WI, Fouad MT, Soriano JM, Mañes J, Micó L (2014). Listeria spp. and Enterobacteriaceae group in sandwiches of meat and meat products. British Microbiology Research Journal, 4(4): 360. 